\title{
Implementation of Disturbance Attenuation Controller Based on Frequency Estimation
}

\author{
Tatsuo Narikiyo Member (Toyota Technological Institute and RIKEN BMC Center) \\ Katsuhiko Fuwa Non-member (Nagoya Institute of Technology) \\ Takeshi Murano Non-member (Toyota Technological Institute)
}

Keywords: disturbance observer, frequency estimator, adaptive notch filter

In this paper, a design method of disturbance attenuation system that can cope with the frequency variation (DOFV) is proposed. The main idea of this design method is to combine DOFV with frequency estimator (adaptive notch filter:ANF) that can estimate disturbance frequency in real time.

We consider a pure sinusoidal signal

$$
d(t)=k \sin \omega_{*} t, \omega_{*}>0,
$$

where $\omega_{*}$ is unknown frequency and $k$ is an amplitude, $k>0$, is also unknown. To estimate the unknown frequency we introduce the ANF described by following dynamical system.

$$
\left\{\begin{array}{c}
\ddot{z}(t)+2 \zeta \omega(t) \dot{z}(t)+\omega(t)^{2} z(t)=\omega(t)^{2} d(t) \\
\dot{\omega}(t)+\gamma z(t)\left\{\omega(t)^{2} d(t)-2 \zeta \omega(t) \dot{z}(t)\right\}=0
\end{array}\right.
$$$$
\ldots \ldots \ldots \ldots \ldots \cdots \cdots \cdots(2)
$$

Where $\omega(t)$ represents the estimated frequency, $\zeta>0$ and $\gamma>0$ are tuning parameters to relieve the conflict between estimation speed and noise sensitivity.

The overall disturbance attenuation system is depicted in Fig. 1. $G_{p}(s)$ represents a given plant, $r(s), u(s), y(s)$ and $e(s)$ are reference input, control input, measurement output and error signal, respectively. $\hat{K}$ is the state feedback gain matrix to asign desired poles to the closed loop system. $C_{e}, C_{y}$ and $\hat{C}_{d a l}$ are controllers of DOFV. $G_{p_{-} s u b}(s)$ can be given arbitrarily if it is proper stable transfer function.

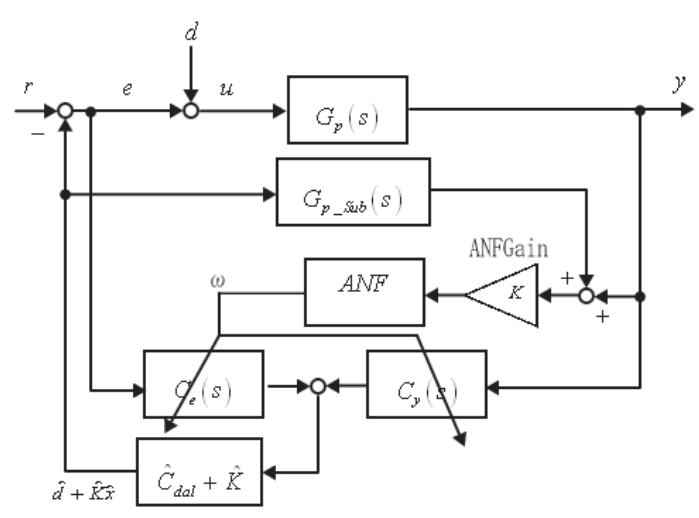

Fig. 1. Block diagram of DOFV with ANF
To demonstrate the usefullness of this control system we apply to experimental system depicted in Fig. 2. By the identification method based on frequency response the dynamical model of the experimental system is obtained as

$$
G_{p}(s)=\frac{2100}{s^{2}+5.845 s+3.282 \times 10^{2}} .
$$

Fig. 3 shows measurement output controlled by the proposed disturbance attenuation system. This result demonstrates the effectiveness of the proposed disturbance attenuation system.

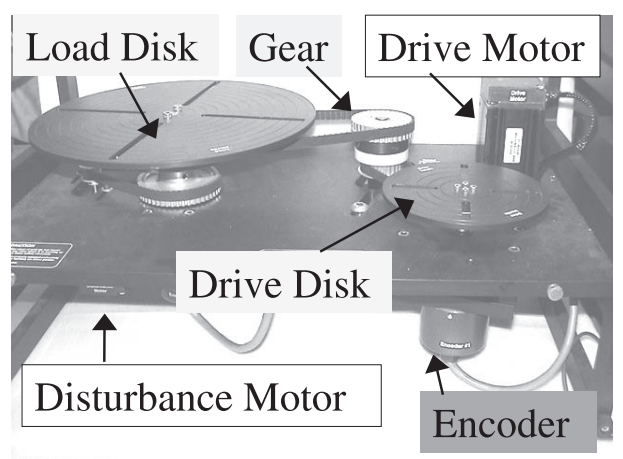

Fig. 2. Experimental system

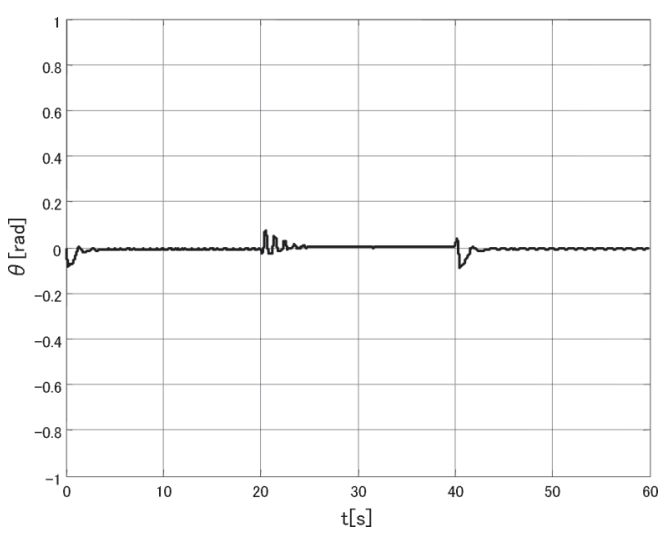

Fig. 3. Disturbance response with proposed control 


\title{
周波数推定に基づく外乱抑制制御系の実装
}

\author{
正 員 成清 辰生* 非会員 不破 勝彦** \\ 非会員 村野 剛志***
}

\author{
Implementation of Disturbance Attenuation Controller Based on Frequency Estimation
}

Tatsuo Narikiyo*, Member, Katsuhiko Fuwa**, Non-member, Takeshi Murano***, Non-member

A well-known control system that can reduce the adverse effects of disturbances is a disturbance observer. Whenever we apply disturbance observer, disturbance frequency should be known and constant. However, in many cases of industrial systems disturbance frequency is varied for some frequency range. Therefore, it may be difficult to reduce the adverse effect of such disturbance by use of the traditional disturbance observer. In this paper, a design method of disturbance attenuation system that can cope with the frequency variation (DOFV) is proposed. The main idea of this design method is to combine DOFV with frequency estimator that can estimate disturbance frequency in real time. Even though the proposed disturbance attenuation system is low degree and low gain controller, it has superior steady state characteristic. Numerical simulations and experiments show the usefulness of the proposed disturbance attenuation system.

キーワード : 外乱オブザーバ, 周波数推定, 適応ノッチフィルター

Keywords: disturbance observer, frequency estimator, adaptive notch filter

\section{1. はじめに}

外乱抑制問題は，重要な制御問題の一つとして数多くの 研究が行なわれてきた。例えば，高ゲイン $H_{\infty}$ オブザー バによる完全観測 (1) や高ゲイン未知入力オブザーバ (2) な どを用いた未知外乱抑制制御系が提案されている。これら の手法は，ある範囲に周波数スペクトルを持つ外乱に対し て有効であることが知られているが，高ゲインに起因する ノイズ対応が問題となっている。一方，単一周波数の外乱 に対しては, 繰返し制御系 ${ }^{(3)}$ や外乱オブザーバ (4)による 外乱抑制制御系が提案されている。これらの手法は直流あ

\footnotetext{
* 豊田工業大学

于 468-8511 名古屋市天白区久方 2-12-1

Toyota Technological Institute

2-12-1 Hisakata, Tempaku, Nagoya 468-8511

理化学研究所 BMC センター

₹ 463-0003 名古屋市守山区下志段味 3-8-31 RIKEN BMC Center

3-8-31 Shimoshidami, Moriyama, Nagoya 463-0003

*** 豊田工業大学

于 468-8511 名古屋市天白区久方 2-12-

Toyota Technological Institute

2-12-1 Hisakata, Tempaku, Nagoya 468-8511

** 名古屋工業大学

T 466-8555 名古屋市昭和区御器所町

Nagoya Institute of Technology

Gokisocho, Shouwa, Nagoya 466-8555
}

るいは固定周波数成分を有する外乱に対して設計されるた め, 外乱周波数が既知である必要がある。したがって, 外 乱周波数が未知な場合や変動する場合などに適用すること は困難である。さらに， $H_{\infty}$ 制御を用いて共振周波数近傍 で感度関数のゲインを低下させることによって, 周波数の 変動する外乱に対してもその影響を除去しようとする報告 もある(5)。しかしながら, この手法では, 制御性能を高め るために一般的には複雑なループ整形が要求され, そのた め $H_{\infty}$ 制御器が求まらないことがしばしば起こり得る。し たがって，実現を睨むと制御性能が保守的になり易いとい う問題がある(7)。

筆者らは周波数変動を伴う周期性外乱の抑制を目的とした 外乱オブザーバ（周波数変動外乱オブザーバ: Disturbance observer to cope with frequency variation. 以下, DOFV と略記）を提案し，優れた制御効果を確認している ${ }^{(6) \sim(8)}$ 。 しかしながら, DOFVは混入する外乱の周波数が測定でき る仮定の下で周期性外乱を抑制する構成であるため, 実用 上の視点から考えると外乱周波数が測定できない場合には 適用が困難である。そこで, 本研究では外乱周波数が測定 できない場合においても DOFVにより外乱抑制を達成でき るよう, 混入する周期性外乱の周波数を実時間で測定でき る推定器 ${ }^{(9)}$ と DOFV の併合系の構成手法を提案し, 制御 用モータと外乱発生用モー夕から構成される実験装置に実 装する。ここで用いる周波数推定器は非線形力学系で記述 
されており, 外乱周波数を与える極限周期解 (Limit Cycle) への大域的な収束性が保証されている。ただし，この周波 数は一定であることが必要である。このため, 本論文で対 象とする周期性外乱に対して以下の条件を付加する。

（1）マッチング条件を満たす

(2) 未知の単一周波数を持つ

（3）周波数はあらかじめ想定できる範囲内でステップ 状に変化する

（4）周波数が一定值に保たれる時間は十分長い これらの条件を満たす外乱を抑制する外乱抑制制御系を構 成し，その有效性と有用性を実装実験によって実証する。

\section{2. 周波数推定器の設計}

本章では文献 (9) に従いオンラインで正弦波の周波数を 推定できる周波数推定器の構成について述べた後, シミュ レーションによりその推定効果を確認する。

$\langle\mathbf{2} \cdot \mathbf{1}\rangle$ 周波数推定器の構成 ${ }^{(9)}$ 測定可能で単一周波 数の正弦波信号 $d(t)$

$$
d(t)=k \sin \omega_{*} t, \quad \omega_{*}>0 .
$$

に打ける周波数 $\omega_{*}$ の推定器を提案する。この推定器は Adaptive Notch Filter（以下, ANF) と呼ばれ，ノッチ フィルタがもつ周波数特性を利用して推定を実現する。具 体的には，フィル夕出力からの情報を用いてノッチ周波数 を調整する'時変フフィル夕を形成して周波数推定を達成し ている。

上述の ANF は, $\omega(t)$ を推定する周波数とすると, 減衰 係数 $\zeta(>0)$, 適応速度 $\gamma(>0)$ の 2 つの設計パラメー夕を 与えることで $(2)$ 式のような簡単な連立微分方程式で表さ れる。

$$
\left\{\begin{array}{l}
\ddot{z}(t)+2 \zeta \omega(t) \dot{z}(t)+\omega(t)^{2} z(t)=\omega(t)^{2} d(t) \\
\dot{\omega}(t)+\gamma z(t)\left\{\omega(t)^{2} d(t)-2 \zeta \omega(t) \dot{z}(t)\right\}=0
\end{array}\right.
$$

ここで, 状態空間を $\left[\begin{array}{lll}z(t) & \dot{z}(t) & \omega(t)\end{array}\right]^{T}$ とすれば, $(2)$ 式 は 3 次の力学系となる。 $\hat{k}, \omega_{0}$ を, 入力正弦波の振幅 $k$, 周 波数 $\omega_{*}$ の初期推定量として, ANF の初期条件を

$$
\left[\begin{array}{lll}
z\left(t_{o}\right) & \dot{z}\left(t_{o}\right) & \omega\left(t_{o}\right)
\end{array}\right]^{T}=\left[\begin{array}{lll}
-\frac{\hat{k}}{2 \zeta} & 0 & \omega_{o}
\end{array}\right]^{T}
$$

のように設定すると，(2) 式の解軌道はつぎの周期軌道に 収束する。

$$
\begin{aligned}
& {\left[\begin{array}{lll}
z(t) & \dot{z}(t) & \omega(t)
\end{array}\right]^{T}} \\
& =\left[\begin{array}{lll}
-\frac{k}{2 \zeta} \cos \omega_{*} t & \frac{k}{2 \zeta} \omega_{*} \sin \omega_{*} t & \omega_{*}
\end{array}\right]^{T}
\end{aligned}
$$

ここで， $\omega_{*}$ が外乱周波数である。

本稿ではこの ANF を利用し，入力する単一周波数の正 弦波を制御対象の観測出力に置き換え，混入した外乱の周 波数 $\omega_{*}$ を推定する。ただし，実装にあたっては，外乱が
未知であるため, ANFへの入力信号として外乱信号を用 いることはできない。そこで, Matlab·Simulink 上に構 成したANFを DSP に実装し，入力信号として制御対象か らの出力信号を用いる。制御対象は線形であるから, 出力 信号は外乱の周波数成分を持った信号となり，ANFへの入 力信号として機能する。

ここで, ANF の初期条件と 2 つの設計パラメー夕の選定 について説明する。ANF の周期軌道 $[z(t) \dot{z}(t) \omega(t)]^{T}=$ $\left[-\frac{k}{2 \zeta} \cos \omega_{*} t \frac{k}{2 \zeta} \omega_{*} \sin \omega_{*} t \omega_{*}\right]^{T}$ は大域的な安定性が保証 されている。従って, ANFの初期条件は任意に選定する ことができるが，後述するシミュレーション結果にも示さ れているように, 初期条件によって安定周期軌道への収束 時間やオーバーシュートの大きさなどが変化する。これら は, $\gamma$ や $の$ 值との相対的な関係にも影響されるが, 理論 的な解析は困難である。また, 周期軌道の近傍に初期条件 を設定できれば，良好な収束性を得ることができるが，未 知な外乱に対して周期軌道を予測することはできない。こ のため, 現実的な対応として, 実験やシミュレーションで は $\left[\begin{array}{lll}z(0) & \dot{z}(0) & \omega(0)\end{array}\right]^{T}=\left[\begin{array}{lll}0 & 0 & \omega_{0}\end{array}\right]^{T}$ としている。ただし， $\omega_{0}$ は任意の值である。一方, 減衰定数 $\zeta$ や適応速度 $\gamma$ は理 論的に設計することが困難なため, これらの選定はシミュ レーションにより試行錯誤的に行なわれる。

\section{$\langle 2 \cdot 2\rangle \quad$ シミュレーションによる ANF の動作の確認}

ここでは制御系設計 CAD ソフト MATLAB を用い，(2) 式に示した ANF のシミュレーションを行ない, その有用 性を確認する。Fig. 1 は ANF 設計パラメー夕を共に 0.1, 初期条件を $\left[\begin{array}{lll}z_{1} & z_{2} & z_{3}\end{array}\right]^{T}=\left[\begin{array}{ccc}0 & 0 & 2 \pi \times 16\end{array}\right]^{T}$ とし, 入 力正弦波の振幅を $k=1$, 周波数は $\omega_{*}=2 \pi \times 14 \sim 2 \pi \times 18$ の範囲内で， 5 秒間隔でランダムに变化させた場合のシミュ レーション結果を表している。階段状に変化する周波数を 正確に推定していることがわかる。Fig. 2 は ANF の推定 動作を状態空間上で表現したものである。周波数の変動に 対応して, 一定の $z_{3}$ の值, すなわち $\omega_{*}$ をもつ極限周期軌 道が生成されていることが確認できる。

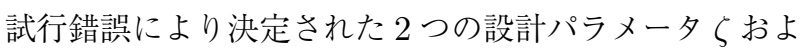

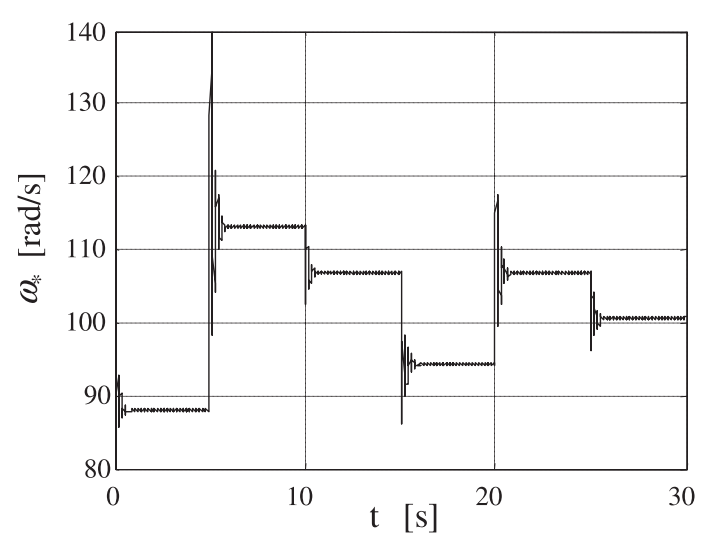

Fig. 1. Estimation of step-like varied angular velocity 


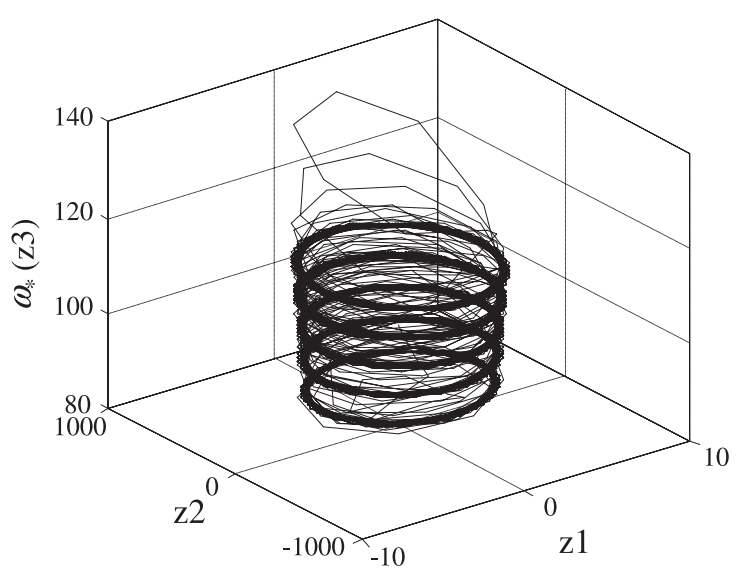

Fig. 2. Limit cycles of ANF

び $\gamma$ は任意に調整を図ることで周波数推定曲線の過渡特性, 定常特性の改善が可能である。しかしながら, 双方の設計 パラメータの間にはトレードオフの関係があり，その決定 には注意を要する。

\section{DOFV の構成と ANF との併合系の構築}

〈3・1〉 DOFV の構成法 ${ }^{(6)}$ DOFVのブロック線図 を Fig. 3 に示す。 $G_{p}(s)$ は制御対象を表し, $r(s), u(s), y(s), e(s)$ はそれぞれ目標入力, 制御入力, 観測出力, 外乱そして目標 入力と外乱推定量との偏差である。ただし，本論文では外 乱に対するレギュレーション問題を扱うため, 以後, シミュ レーションおよび実験においても目標入力 $r$ は $r(s)=0$ と する。また, $\hat{K}$ は $r(s)$ から $y(s)$ への閉ループ系の極を指定 するための状態フィードバックゲインである。本構成法は外 乱周波数が直接測定できる仮定のもとで，スケジューリン グ手法による状態オブザーバを用い，ある周波数範囲での 外乱抑制を実現する。以下，同一次元オブザーバで DOFV の設計法を示す。

制御対象の状態方程式および伝達関数 $G_{p}(s)$ は

$$
\begin{aligned}
& \dot{x}(t)=A x(t)+B u(t) \\
& y(t)=C x(t) \\
& G_{p}(s)=C\left(s I_{n}-A\right)^{-1} B .
\end{aligned}
$$

ただし, $x(t)$ は $n$ 次元状態変数, $u(t)$ は 1 次元制御入力, $y(t)$ は $m$ 次元観測出力であり, $(A, B)$ は可制御, $(C, A)$ は可観測。また, 外乱 $d(t)$ はマッチング条件 (5) を満たし ているものとする。外乱 $d(t)$ は $(1)$ 式と同じような

$$
d(t)=k \sin \omega t
$$

とする。ここで角周波数 $\omega$ は準静的過程を満足するように 変動すると仮定する。このとき，外乱 $d(t)$ はつぎの状態方 程式で表される。

$$
\begin{aligned}
\dot{x}_{d a l}(t) & =A_{d a l} x_{d a l}(t) \\
d(t) & =C_{d a l} x_{d a l}(t)
\end{aligned}
$$

ただし，

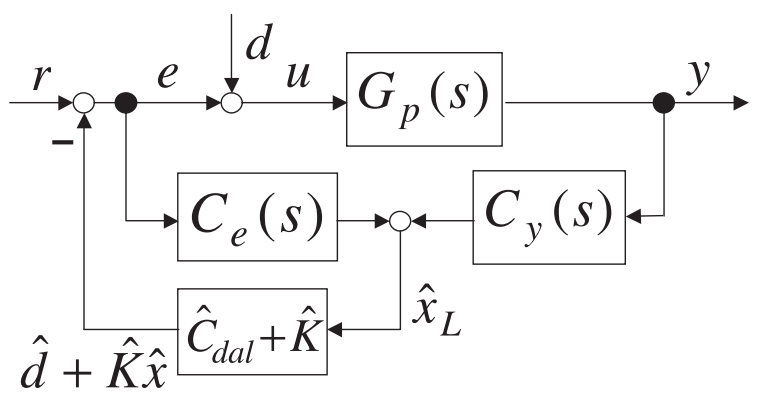

Fig. 3. Block diagram of DOFV

$$
A_{d a l}=\left[\begin{array}{cc}
0 & -\omega \\
\omega & 0
\end{array}\right], C_{d a l}=\left[\begin{array}{ll}
1 & 0
\end{array}\right]
$$

である。外乱の状態方程式を含んだ拡大系を示すと (6) 式 のようになる。

$$
\begin{aligned}
\dot{x}_{L}(t) & =A_{L} x_{L}(t)+B_{L} e(t) \\
y(t) & =C_{L} x_{L}(t)
\end{aligned}
$$

ただし，

$$
\begin{array}{cc}
x_{L}(t)=\left[\begin{array}{c}
x(t) \\
x_{d a l}(t)
\end{array}\right], & A_{L}=\left[\begin{array}{cc}
A & B C_{d a l} \\
O_{2 \times n} & A_{d a l}
\end{array}\right] \\
B_{L}=\left[\begin{array}{c}
B \\
O_{2 \times 1}
\end{array}\right], & C_{L}=\left[\begin{array}{ll}
C & O_{m \times 2}
\end{array}\right]
\end{array}
$$

であり，外乱 $d(t)$ は

$$
d(t)=\hat{C}_{d a l} x_{L}(t), \quad \hat{C}_{d a l}=\left[\begin{array}{ll}
O_{1 \times n} & C_{d a l}
\end{array}\right] \cdots
$$

で表される。(6) 式において, $\left(C_{L}, A_{L}\right)$ が可観測であるた めの条件

(1) $(C, A)$ が可観測である。

(2) $G_{p}(s)$ は虚軸上にて不変零点 ${ }^{(5)(10)}$ を持たない。 ならば，拡大系に対するオブザーバが構成可能である。それ ゆえ, 制御対象 $G_{p}(s)$ は条件（1）および（2）を満足する ものとして, 状態 $x_{L}(t)$ を同一次元オブザーバにて推定し, (7) 式より周波数変動を伴う周期性外乱を推定する。 $x_{L}(t)$ の推定量を $\hat{x}_{L}(t)$ とすれば，オブザーバの状態方程式と外 乱 $d(t)$ の推定量 $\hat{d}(t)$ は

$$
\begin{aligned}
\dot{\hat{x}}_{L}(t) & =\hat{A}_{\hat{x}_{L}}(t)+B_{L} e(t)+G y(t) \\
\hat{d}(t) & =\hat{C}_{\text {dal }} \hat{x}_{L}(t)
\end{aligned}
$$

で与えられる。 $G$ は $\hat{A}=A_{L}-G C_{L}$ を安定行列とするオブ ザーバゲインである。また， $A_{L}$ は $\omega$ の関数となっており, $\omega$ の変動範囲においてオブザーバが安定となるよう $G$ も $\omega$ の值に応じて変化させる。 $\omega$ の変動範囲を $\omega_{1} \leq \omega \leq \omega_{2}$ と すると，その端点における重み行列を

$$
\begin{aligned}
& q_{1}=\frac{\omega_{2}-\omega}{\omega_{2}-\omega_{1}}, q_{2}=\frac{\omega-\omega_{1}}{\omega_{2}-\omega_{1}}, \\
& q_{1}+q_{2}=1, q_{1}, q_{2} \geq 0 \ldots \ldots
\end{aligned}
$$

とし, $A_{L}, G$ を 


$$
A_{L}=q_{1} A_{1}+q_{2} A_{2}, \quad G=q_{1} G_{1}+q_{2} G_{2} \cdots
$$

とすると, $\hat{A} は$

$$
\hat{A}=q_{1}\left(A_{1}-G_{1} C_{L}\right)+q_{2}\left(A_{2}-G_{2} C_{L}\right) \cdots
$$

のようなポリトープ形式で表される。これが安定であるた めには，つぎの LMI

$$
\begin{array}{r}
X>O \\
X A_{i}+A_{i}^{T} X-M_{i} C_{L}-C_{L}^{T} M_{i}^{T}<O \\
M_{i}=X G_{i}, i=1,2
\end{array}
$$

の解 $X$ 㧍よび $M_{i}(i=1,2)$ が存在すればよい。この LMI を解くことで，オブザーバを安定とする $G$ が求まる。

なお，今回は $G$ を求める LMI に加え極領域を指定す る LMI を考慮し，これらを連立させて解くことで外乱才 ブザーバの速応性と定常特性の改善を図った。詳細は文 献 (6) (11)〜(13) を参照されたい。

これにより, Fig. 3 に扔ける周波数依存の $C_{e}(s)$ 抢よび $C_{y}(s)$ は (13) 式により与えられる。

$$
\begin{aligned}
& C_{e}(s)=\left(s I_{n+2}-\hat{A}\right)^{-1} B_{L} \\
& C_{y}(s)=\left(s I_{n+2}-\hat{A}\right)^{-1} G
\end{aligned}
$$

$\langle 3 \cdot 2\rangle$ 併合系の構成 本節では, 外乱周波数が直接測 定できない場合においても，ANFを用いてDOFVを適用 できる併合系の構成手法を提案する。併合系のブロック線 図を Fig. 4 に示す。本手法では, 外乱の周波数を制御対象 の観測出力を用いて推定する。しかし，観測出力は外乱抑 制により, 零へと収束するため周波数推定が困難になる。ま た, ANFへの入力振幅も周波数推定へ影響を与えるため, これらを補正する必要がある。すなわち, ANFにより周波 数が正確に推定されると，DOFVによる外乱フィードバッ クによって出力信号から外乱が除去される。ANF は本来, 外乱を入力として周波数推定を行うため，外乱周波数成分 が含まれない信号を入力信号として印加した場合，周波数 推定を行うことができなくなり，誤った周波数を DOFVへ 返すことになる。この結果, DOFV は外乱を推定すること ができず，再び，出力信号は外乱の影響を受けることにな

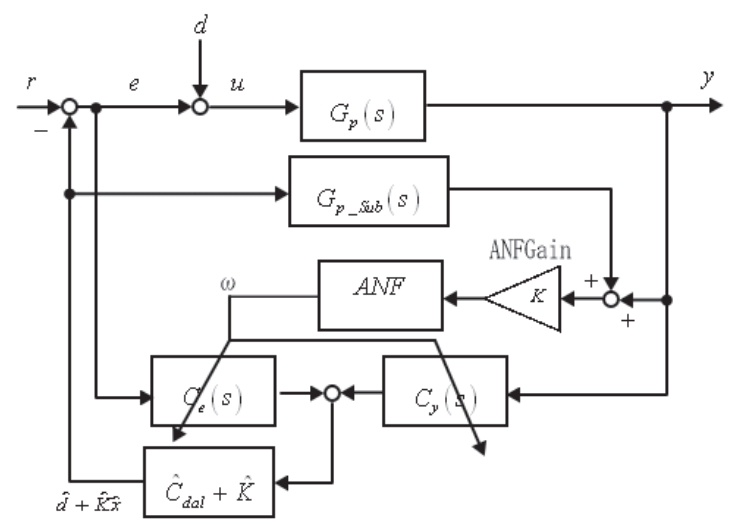

Fig. 4. Block diagram of DOFV with ANF
る。そして, 外乱周波数を持った出力信号に対して, ANF が周波数推定を開始し，DOFVによる外乱フィードバック の効果が現れる。このように，外乱フィードバックの効果 を維持するためには，常に外乱信号が ANFへ入力される 機構が必要となる。そこで, Fig. 4 のように ANFへの入力 チャンネルに $G_{p_{\text {_sub }}}(s)$ と定数ゲイン $K$ を付加し, 信号補

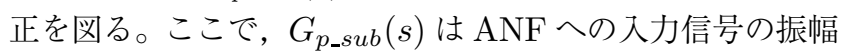
補正のために挿入する。すなわち, 推定外乱のフィードバッ クによって観測出力から除去された外乱成分を ANF へ再 帰させることで, 周波数推定を持続させる働きをする。こ のため, $G_{p_{\text {_sub }}}(s)$ は安定かつプロパな伝達関数であれば任 意であるが, ANF のパラメータが制御対象の特性に依存し て設計されるため, 制御対象と同一の周波数特性を持って いるほうが好ましい。一方, 制御対象が不安定な場合, 外 乱の周波数带域でゲインと位相が一致する安定な伝達関数 を用いることが望ましいが，次節のシミュレーション結果 に示されているように単なる定数ゲインとしても性能の劣 化はほとんど見られない。定数ゲインは ANF の大域的安 定性から，任意に大きくすることができるが，ステップで 変化する周波数に対して推定值に大きなオーバーシュート が生じ, 収束が非常に遅くなる。このため, 事前にシミュ レーションにより, 定数ゲインと ANF の設計パラメータ $\zeta, \gamma$ との調整を行なう必要がある。

\section{4. シミュレーション}

$\langle\mathbf{4} \cdot \mathbf{1}\rangle$ 安定なシステム 係数行列が以下のような (3) 式の制御対象を考える。

$$
\begin{aligned}
A & =\left[\begin{array}{cc}
-5.845 & -328.2 \\
1 & 0
\end{array}\right], \quad B=\left[\begin{array}{l}
1 \\
0
\end{array}\right], \\
C & =\left[\begin{array}{ll}
0 & 2100
\end{array}\right] \ldots \ldots \ldots \ldots \ldots \ldots \ldots \ldots \ldots \ldots
\end{aligned}
$$

このとき $(A, B)$ は可制御, $(C, A)$ は可観測であり, $G_{p}(s)$ は虚軸上に不変零点を持たない。(14) 式は, 後に示す実験 装置の伝達関数の実現である。実験装置はディスクの回転 系であることから, 出力 $y(t)$ はディスク回転角, すなわち, $y(t)=\theta(t)$ である。また, 外乱は一定振幅で周波数が階段 状に変化するものとし，ANF の初期条件および設計パラ メータ $\gamma, \zeta を$

$$
\begin{aligned}
& {\left.\left[\begin{array}{lll}
z(t) & \dot{z}(t) & \omega(t)
\end{array}\right]^{T}\right|_{t=0}=\left[\begin{array}{lll}
0 & 0 & 2 \pi
\end{array}\right]^{T},} \\
& \gamma=0.1, \quad \zeta=0.45 \ldots \ldots \ldots \ldots \ldots \ldots \ldots
\end{aligned}
$$

として, 3 章の議論から周波数依存の $C_{e}(s)$ 拉よび $C_{y}(s)$ を求める。このとき，オブザーバゲイン $G_{1}, G_{2}$ は $(12)$ 式 の LMI と conic sector を考慮した極領域指定 (secter 角 度 $\left.88^{\circ}\right)$ LMI を用いて次のように求めた。

$$
\begin{aligned}
G_{1}^{T} & =\left[\begin{array}{llll}
12.2655 & 0.2880 & 276.644 & 32.0694
\end{array}\right] \\
G_{2}^{T} & =\left[\begin{array}{llll}
11.3457 & 0.2660 & 251.640 & 12.7449
\end{array}\right]
\end{aligned}
$$




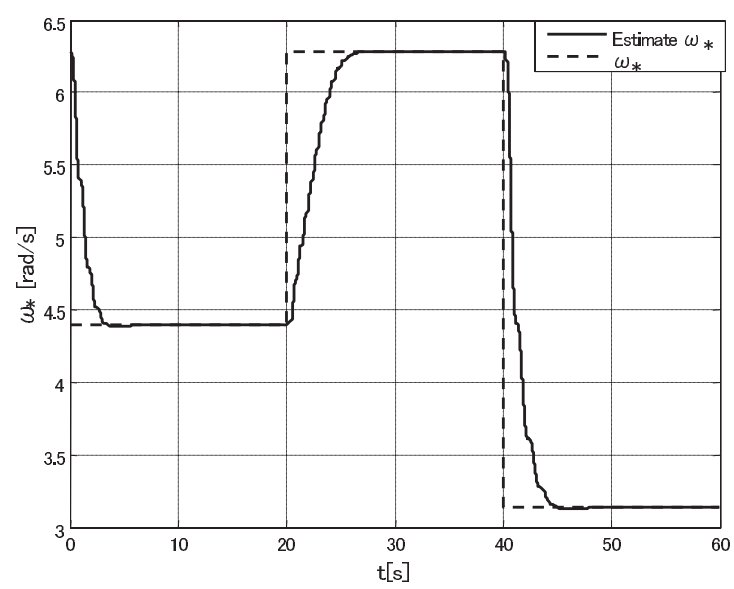

Fig. 5. Estimation of angular velocity $\omega_{*}$ for stable plant

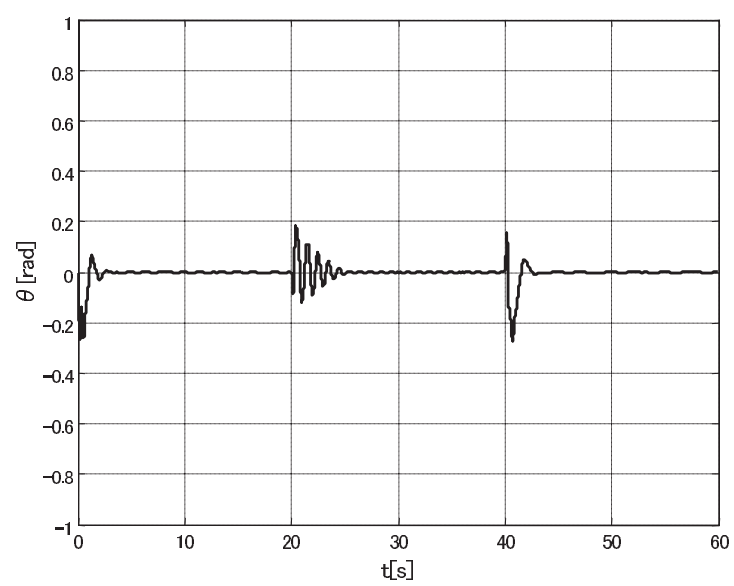

Fig. 6. Disturbance response with proposed control for stable plant

$G_{p_{\text {_sub }}}(s)$ は制御対象と同じ伝達関数とした。 $A$ は安定行列 であることから文献 (6) に従い， $\hat{K}=O_{1 \times 2}$ として Fig. 4 の併合系を構成し, ANF による観測出力からの周波数推定 を用いて，DOFVによる外乱抑制のシミュレーションを行 なった。ANF の出力結果を Fig. 5 に, 外乱抑制を行なっ た場合の出力応答を Fig. 6 に, 行なわない場合を Fig. 7 に 示す。周波数が変化したときに, 多少の遅れは生ずるもの の, 定常的には外乱の周波数推定を達成し, DOFVにより 周期性外乱を抑制できることが確認できる。

〈4・2〉 不安定なシステムつざに不安定な制御対象に 対して ANF およびDOFV の併合系を構成し, シミュレー ションを行なう。(3) 式の制御対象の係数行列がつぎのよう な状態方程式を考える。

$$
A=\left[\begin{array}{ll}
4 & -3 \\
2 & -1
\end{array}\right], B=\left[\begin{array}{l}
0 \\
1
\end{array}\right], C=\left[\begin{array}{ll}
1 & 0
\end{array}\right] \cdots
$$

これは, 不安定根 1,2 を持つ。 $(A, B)$ は可制御であるの でシステムを安定とする状態フィードバック係数 $\hat{K}$ を求 めることができる。固有值を $-5,-6$ とする $\hat{K}$ を求める と $\hat{K}=\left[\begin{array}{ll}-28 & 14\end{array}\right]$ となる。また，このとき $(C, A)$ は可

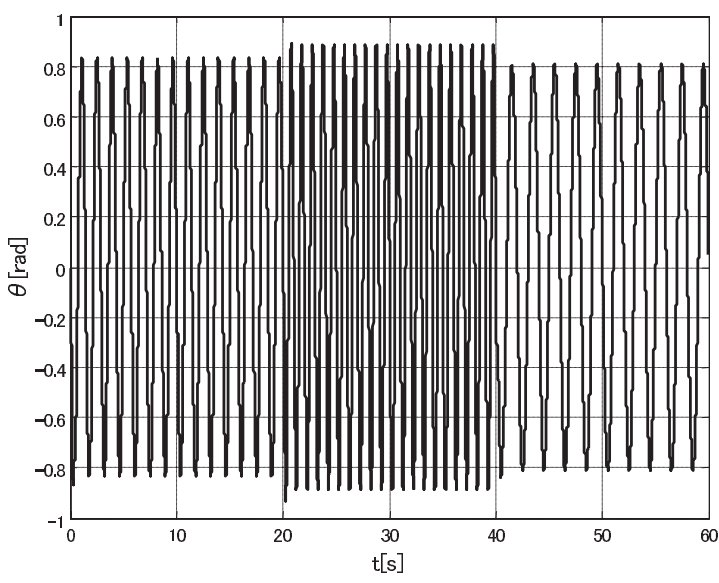

Fig. 7. Disturbance response without control for stable plant

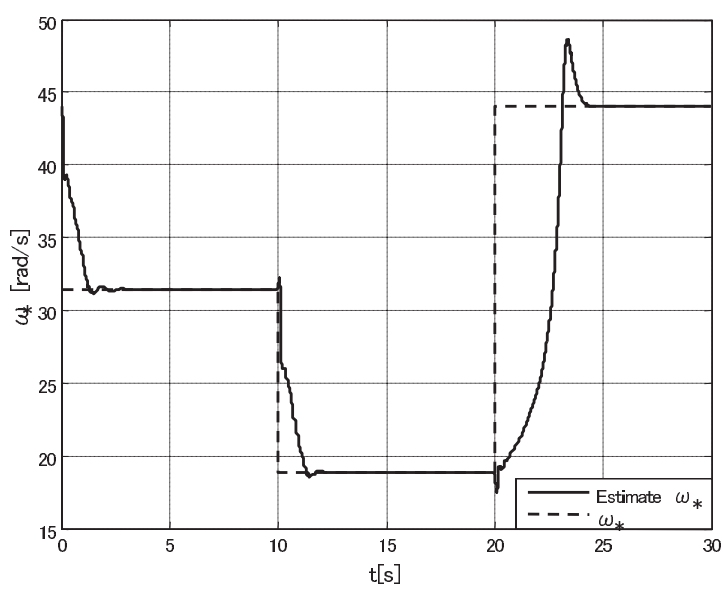

Fig. 8. Estimation of angular velocity $\omega_{*}$ for unstable plant

観測であり, $G_{p}(s)$ は虚軸上にて不変零点を持たない。こ れらを用いて前回と同様 Fig. 4 の併合系を構成する。ただ し, $G_{p_{-} s u b}(s)$ は定数ゲイン $(1000)$ とした。オブザーバ ゲイン $G_{1}, G_{2}$ は (12) 式の LMI と conic sector を考慮し た極領域指定 (secter 角度 $\left.89^{\circ}\right) \mathrm{LMI}$ を用いて次のように求 めた。

$$
\begin{aligned}
G_{1}^{T} & =\left[\begin{array}{llll}
0.0119 & -0.4355 & -7.9343 & -0.6331
\end{array}\right] \times 10^{5} \\
G_{2}^{T} & =\left[\begin{array}{llll}
0.0118 & -0.4316 & -7.8289 & -0.3900
\end{array}\right] \times 10^{5}
\end{aligned}
$$

外乱は一定振幅で周波数が階段状に变化するものとし, ANF の初期条件及び設計パラメータ $\gamma, \zeta を$

$$
\begin{aligned}
& {\left.\left[\begin{array}{lll}
z(t) & \dot{z}(t) & \omega_{*}
\end{array}\right]^{T}\right|_{t=0}=\left[\begin{array}{lll}
0 & 0 & 2 \pi \times 7
\end{array}\right]^{T},} \\
& \gamma=0.1, \quad \zeta=0.45 \text {. }
\end{aligned}
$$

とし，シミュレーションを行なった。ANF の出力結果を Fig. 8 に, 外乱抑制を行なった場合のシステムの出力結果 を Fig. 9 に, Fig. 10 に状態フィードバックのみで, 外乱 抑制を行なわなかった時の結果を示す。不安定なシステム では, 安定なシステムに比べ推定周波数が一致していない 


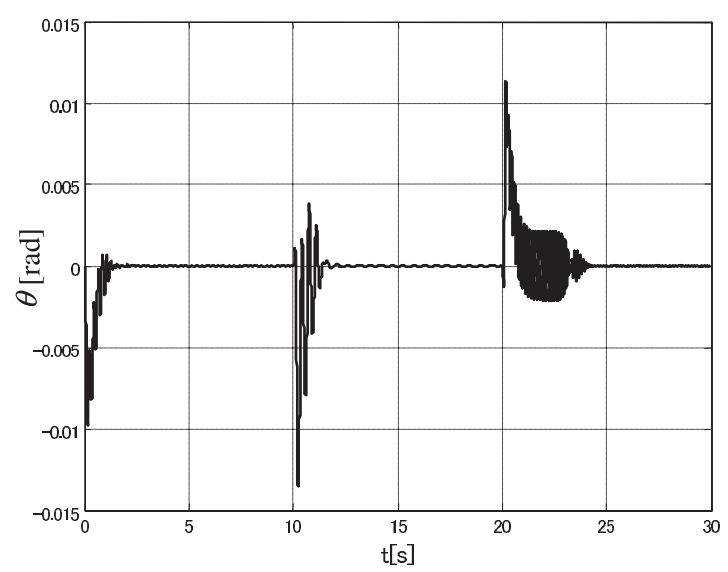

Fig. 9. Disturbance response with proposed control for unstable plant

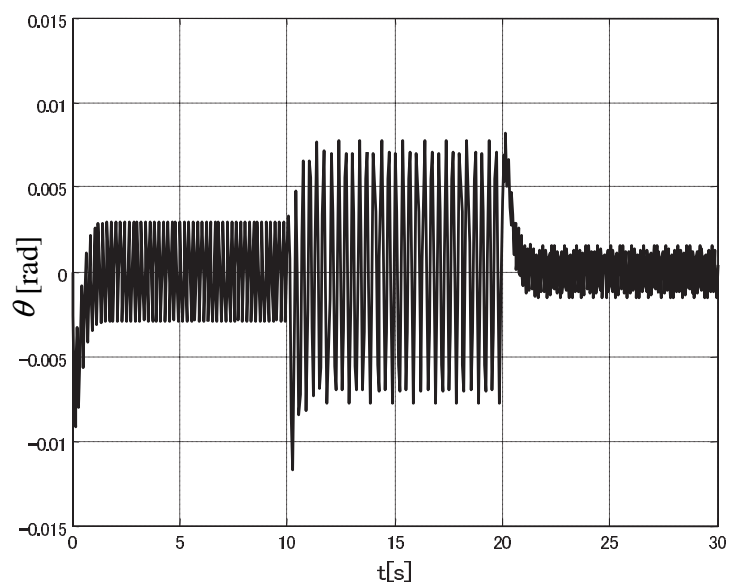

Fig. 10. Disturbance response with state feedback for unstable plant

ときの乱れが大きくなっており，周波数が変化したときに， 多少の遅れとオーバーシュートを生じた。しかしながら，定 常的には外乱の周波数推定が達成されて抢り，DOFVによ り周期性外乱が抑制されることが確認できる。

\section{5. 実装実験}

本論文で提案した ANF と DOFV の併合系の有効性を 実装実験にて確認する。

$\langle\mathbf{5} \cdot \mathbf{1}\rangle$ 実験装置 Fig. 11, Fig. 12 に実験装置の全体 構成を示す。2つのモー夕は制御用モー夕 (Drive Motor) と外乱発生用モー夕 (Disturbance Motor) であり, モー夕 への入力信号は指令トルク, 出力信号はモータの回転角度 である。制御用モータはドライブディスクを駆動し，外乱 発生用モー夕はロードディスクを駆動する。それぞれのディ スクはギアを介してガラス繊維を組み込んだ高パワーの動 力伝達用タイミングベルト (米国 GATES 社製 Power Grip 260XL037) で連結されている。この実験装置はデイスクや DC モー夕抢よびギアからなる多慣性系であるが，使用す る夕イミングベルトは実質的に無弾性と考えることができ るため，これらの慣性が結合した 1 慣性系として回転する。

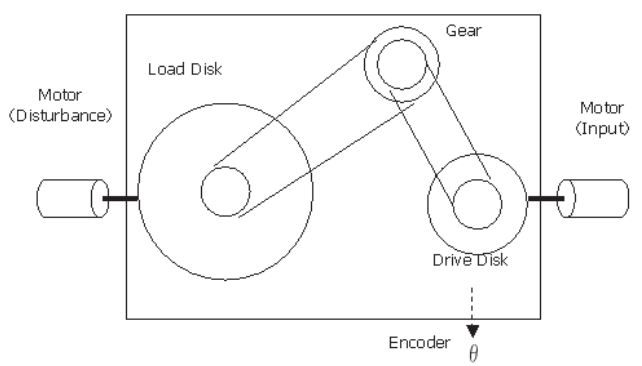

Fig. 11. Electromechanical plant

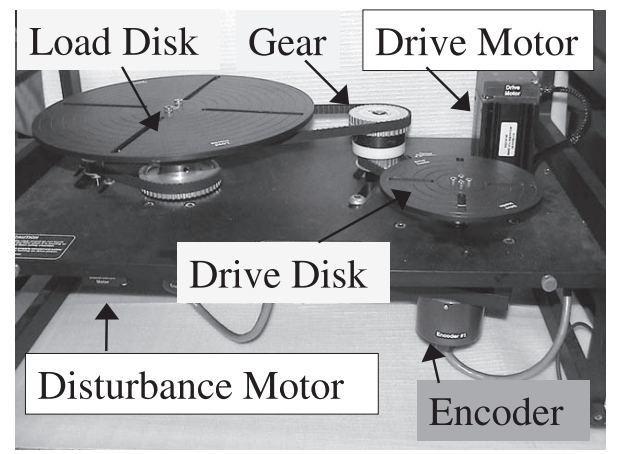

Fig. 12. Experimental system

2 つのディスクの回転出力はドライブディスクに設けられ たエンコーダにより角度として検出される。また, 計算機 にて生成された各制御則は DSP 上で実現されており, 観 測出力に応じて制御入力を生成し, サーボアンプを介して 入力モータを駆動する。

$\langle\mathbf{5} \cdot \mathbf{2}\rangle$ 制御対象のモデル化 提案した外乱抑制制御 系を実装するため, 外乱モー夕を停止させ, 入力モー夕に 一定振幅の正弦波を周波数 $0.1[\mathrm{~Hz}]$ から $2.5[\mathrm{~Hz}]$ まで変動 させたときのディスクの変位を測定し, 制御対象の入出力 モデルを導出する。ただし，オープンループで正弦波を印 加した場合, モータにはクーロン摩擦などの非線形性の影 響によりドリフトが発生し, 出力信号の測定が困難となる。 このため, 制御対象の原点を安定化する $\mathrm{PD}$ 補償器をマイ ナーループヘ挿入し，ドリフトの発生を抑えた。この PD 補償器を含んだシステムを制御対象とし, 入力モー夕に一 定振幅の正弦波を周波数 $0.1[\mathrm{~Hz}]$ から $2.5[\mathrm{~Hz}]$ まで変動さ せ，CADソフト MATLABを用いて同定を行なった結果， 制御対象の伝達関数は次式のような 2 次系となった。

$$
G_{p}(s)=\frac{2100}{s^{2}+5.845 s+3.282 \times 10^{2}}
$$

な抢，シミュレーションで用いた (14) 式はこの制御対象の 状態空間モデルである。

〈5・3〉 実装実験＼cjkstart求めたモデルに対して ANF および DOFV の併合系を構成してDSP に実装し，サンプリング タイム $2.652[\mathrm{~ms}]$ にて外乱抑制実験を行なう。オブザーバゲ イン $G_{1}, G_{2}$ などの制御器パラメータは全てシミュレーショ ンを行なった $4 \cdot 1$ 節で用いたものと同じである。く $4 \cdot 1$ 節の シミュレーションと同様の外乱を印加した時の外乱抑制結 


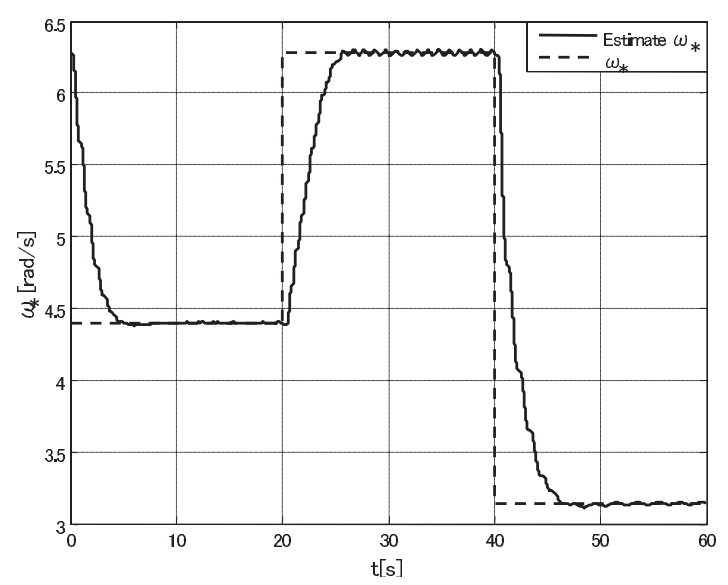

Fig. 13. Estimation of angular velocity $\omega_{*}$

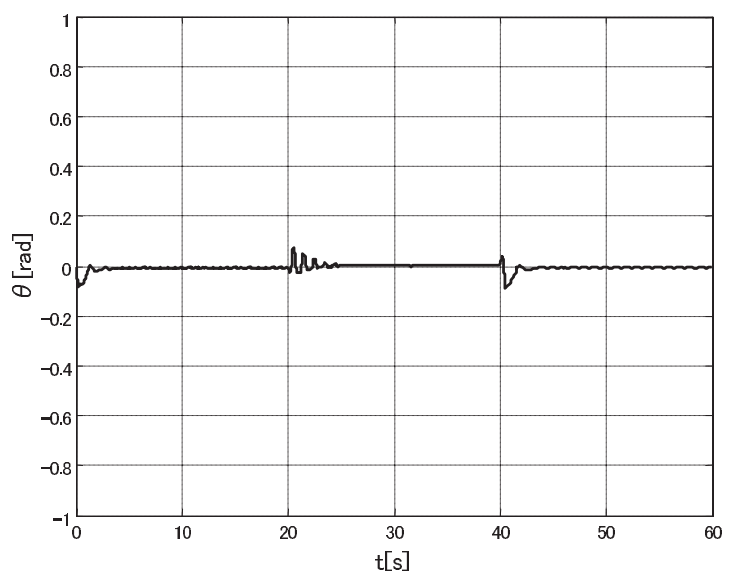

Fig. 14. Disturbance response with proposed control

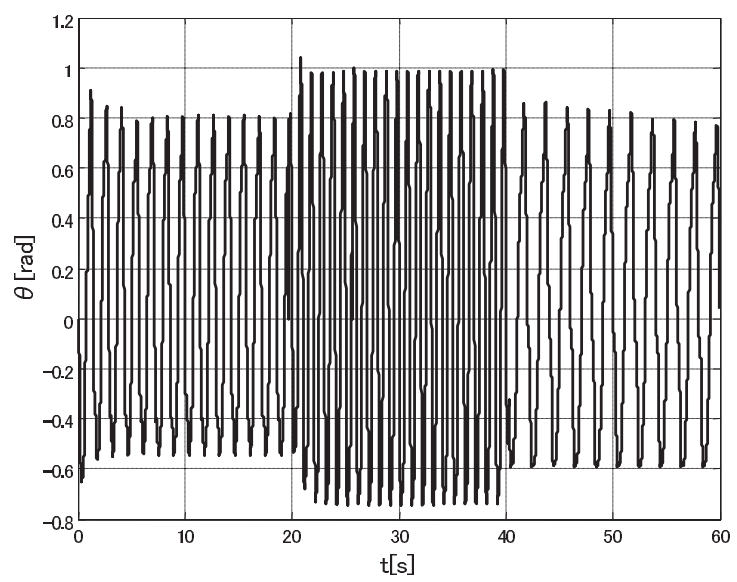

Fig. 15. Disturbance response without control

果を示す。Fig. 13 に ANF の出力結果を, Fig. 14 に外乱 抑制を行なった場合のデイスク位置の出力結果を, Fig. 15 に外乱抑制を行なわない場合の出力結果を示す。周波数推 定がシミュレーション結果よりも若干定常状態において振 動的になっているものの, 実システムからの観測出力より 周波数推定を達成し, 実験に扔いても極めて良好な外乱抑 制性能が達成されていることが確認できる。
〈5・4〉併合系の安定性 ANF，DOFV の併合系の安 定性を考える必要があるが, ANFの出力 $\omega$ は DOFVへの 入力ではなく, ゲインスケジューリング則における情報であ るので, $G_{p_{\text {_sub }}}(s)$ ならびに $\mathrm{ANF}$ が安定のもとで, DOFV が $\omega$ の変動範囲において安定であればよいということに なる。ただし，ANF の推定遅れに対応する時間带での安 定性については注意する必要がある。すなわち，この間は DOFV のゲインスケジューリングによる安定化のための条 件である準静的過程 $\dot{\omega}(t)=0$ が成立しない。したがって, 提案する外乱抑制制御系の安定性は, 周波数変化が生じる 点での安定性については厳密には保証できないことになる。 しかしながら，周波数が一定值に保たれる時間は十分長い という条件の下では, 周波数の変動に伴う過渡状態の影響 は小さく, 周波数の変動が設定された変動領域に存在する 限り DOFVの安定性により閉ループ系の安定化は達成で きる。

\section{6. おわりに}

本研究では, 外乱により励起される振動を抑制するため, ANFを用いた DOFV を構成し, シミュレーションおよび 実装実験により有効性を確認した。シミュレーションと実 験において, 出力応答と周波数推定は極めて良好な結果を 示した。この結果，周波数が測定できない場合に対しても， ANF 用いて観測出力からオンラインで 外乱の周波数推定 することで，DOFVによる優れた低感度特性を有する制御 系を実現することができることが分かった。実験では，安 定な制御対象のみを扱ったが, 不安定な制御対象に対して も, シミュレーションと同様, あらかじめ状態フィードバッ クによってシステムを安定化した後，提案手法を実装する ことで，外乱抑制を達成できる。また，実験に扔ける周波 数推定結果には若干の振動がみられたが，この原因を探る 手順の一つとして, ANF の理論的解析, 特に離散化に伴う 非線形力学系の安定周期解の挙動解析に関する議論が必要 となると考えられる。この議論については, 今後の課題と する。

本研究を遂行するにあたり, 実験装置の構成やシミュレー ションなどに協力いただいた平成 17 年度豊田工業大学卒業 生池場威満氏（現，東邦ガス株式会社）に謝意を表す。ま た, 本研究は, 文部科学省科学研究費補助金（課題番号： (B)19360110）抢よび八イテクリサーチセンター整備事業 の助成を受けて実施された。記して謝意を表す。 (平成 20 年 3 月 14 日受付, 平成 20 年 7 月 28 日再受付)

\section{文献}

(1) M. Fujita, K. Uchida, and F. Matsumura: "Asymptotic $H_{\infty}$ Disturbance Attenuation Based on Perfect Observation", IEEE Trans. Autom. Control, 36-7, pp.875-880 (1991)

(2) K. Sagara, I. Moriyama, K. Kawaguchi, and T. Ishimatsu: "An Observer with a Function of Estimating Unmeasurable Inputs (On an Observer of a Boiler Heating Surface)", T. $\operatorname{JSME}(\mathrm{C})$, Vol.63, No.605, pp.121-127 (1997-1) (in Japanese) 
相楽和男 他：「計測不可能な入力の推定機構をもつオブザーバ（ボ イラ伝熱面のオブザーバの構成について)」, 日本機械学会論文集 (C 編), 63-605, pp.121-127 (1997)

(3) J. She, M. Nakano and L. Wang: "Suppression of Disturbances in Repetitive Control Systems-An Approach Based on Curvature Model of Disturbances-", T. SICE, Vol.37, No.5, pp.397-402 (2001-5) (in Japanese)

余 錦華・中野道雄・王 麗莉：「繰返し制御系における外乱の抑 制—外乱の曲率円弧モデルによるアプローチ—」, 計測自動制御学 会論文集，37, 5, pp.397-402 (2001)

(4) K. Ohnishi, M. Nakano, K. Ohnishi, and K. Miyachi: "Microprocessor-Controlled DC Motor for Load-Insensitive Position Servo System", IEEE Trans. Ind. Elec., Vol.IE-34, No.1, pp.44-49 (1987-2)

(5) T. Mita, M. Hirata, and K. Murata: "Theory of $H_{\infty}$ Control and Disturbance Observer", T. IEE Japan, Vol.115-C, No.8, pp.1002-1011 (1995-8) (in Japanese)

美多 勉・平田光男・村田健一: 「 $H_{\infty}$ 制御と外乱オブザーバの理 論」, 電学論 C, 115, 8, pp.1002-1011 (1995-8)

(6) K. Fuwa and T. Narikiyo: "A Design Method of Disturbance Observer to Cope eith Frequency Variation", T.IEE Japan, Vol.118-C, No.1, pp.127-133 (1998-1) (in Japanese) 不破勝彦・成清辰生 :「周波数変動外乱オブザーバの構成法」, 電学 論 D, 118, 1, pp.127-133 (1998-1)

(7) K. Fuwa and T. Narikiyo: "Implementation of the Vibration Suppression Control System using Disturbance Observer to Cope with Frequency Variation", Trans. JSME, Vol.68, No.674-C, pp.2918-2924 (2002) (in Japanese)

不破勝彦・成清辰生：「周波数変動外乱オブザーバを用いた振動制 御系の実現」, 日本機械学会論文集 C 編, 68-674, pp.2918-2924 (2002)

(8) K. Fuwa, T. Narikiyo, and H. Kawaguchi: "Vibration Control of Flexible Structure Based on the Disturbance Rejection", T. SICE, Vol.39, No.12, pp.1143-1149 (2003-12) (in Japanese) 不破勝彦・成清辰生・川口久雄:「外乱抑制に基づく柔軟構造物の振 動制御」, 計測自動制御学会論文集, 39-12, pp.1143-1149 (2003)

(9) L. Hus, R. Ortega, and G. Damm : "A Globally Convergent Frequency Estimator", IEEE Transactions on Automatic Control, 44-4, 698/713 (1999)

(10) T. Mita: " $H_{\infty}$ Control", Shokodo, pp.18-34 (1994-4) (in Japanese) 美多勉:「 $H_{\infty}$ 制御」, pp.16-133, 昭晃堂 (1994)

(11) H. Kajiwara: "LMI-Based Design of Gain-Scheduled State Feedback to Control Angular Velocity Variations of a Spinning Body", Proceedings of the 35th SICE Annual Conference, II-308D-5, pp.879-880 (1996) (in Japanese) 梶原宏之:「回転体速度変動抑制のためのゲインスケジュールド・状 態フィードバックの LMI ベース設計」，第 35 回計測自動制御学会

予稿集，II, 308D-5，pp.879-880（1996）

（12）原 辰次：「線形行列不等式（LMI）に基づく制御系設計」, SICE セミナーテキスト（ロバスト制御入門），pp.66-78（1995）

(13) A. Fujimori: "Robust Control", coronasha, pp.188-192 (2001)

藤森＼cjkstart篤：「ロバスト制御」, pp.188-192, コロナ社（2001）

成 清 辰 生 (正員) 1978 年名古屋大学応用物理学科卒業,

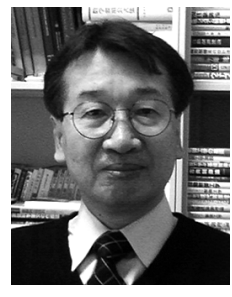
1983 年同大学院情報工学専攻単位取得退学, 同年 通産省工業技術院九州工業技術試験所入所。1990 年豊田工業大学助教授, 1998 年同教授。1993 年 理化学研究所バイオミメティック・コントロール 研究センターフロンティア研究員 (非常勤) 併任。 制御工学, ロボット工学の研究と教育に従事。工 学博士。

不 破 勝 彦

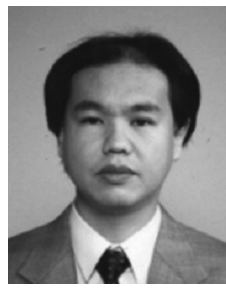

村 野 剛 志

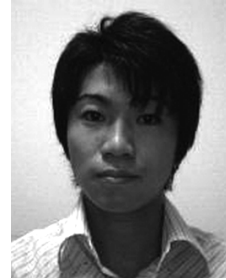

（非会員） 2000 年名古屋工業大学大学院工学研 究科博士後期課程修了。同年, 名古屋工業大学電 気情報工学科助手。制御系設計法の研究に従事。
(非会員) 2004 年徳山工業高等専門学校卒業。同 年矢崎総業株式会社入社。2005 年社会人学生と して豊田工業大学工学部先端工学基礎学科へ内地 留学。2007 年同大学卒業。在学中は外乱抑制制 御に関する研究に従事。 